\title{
Hazard Scenarios Related to Submarine Volcanic-Hydrothermal Activity and Advanced Monitoring Strategies: A Study Case from the Panarea Volcanic Group (Aeolian Islands, Italy)
}

\author{
Davide Romano $\mathbb{D D}^{1,2}$ Alessandro Gattuso $\mathbb{D}^{1},{ }^{1}$ Manfredi Longo $\mathbb{D},{ }^{1}$ Cinzia Caruso, ${ }^{1}$ \\ Gianluca Lazzaro, ${ }^{1}$ Andrea Corbo, ${ }^{1}$ and Francesco Italiano ${ }^{1}$ \\ ${ }^{1}$ Istituto Nazionale di Geofisica e Vulcanologia, Palermo 90146, Italy \\ ${ }^{2}$ Dipartimento di Scienze Matematiche e Informatiche, Scienze Fisiche e Scienze della Terra (MIFT), Università di Messina, \\ Messina 98166, Italy \\ Correspondence should be addressed to Alessandro Gattuso; alessandro.gattuso@ingv.it
}

Received 12 April 2019; Accepted 23 August 2019; Published 13 October 2019

Guest Editor: Alessandro Santilano

Copyright (C) 2019 Davide Romano et al. This is an open access article distributed under the Creative Commons Attribution License, which permits unrestricted use, distribution, and reproduction in any medium, provided the original work is properly cited.

\begin{abstract}
Geohazards associated to submarine hydrothermal systems still represent a tricky enigma to face and solve for the scientific community. The poor knowledge of a submarine environment, the rare and scarce monitoring activities, and the expensive and sometimes complicated logistics are the main problems to deal with. The submarine low-energy explosion, which occurred last November 3, 2002, off the volcanic island of Panarea, highlighted the absence of any hazard scenario to be used to manage the volcanic crisis. The "unrest" of the volcanic activity was triggered by a sudden input of deep magmatic fluids, which caused boiling water at the sea surface with a massive $\mathrm{CO}_{2}$ release besides changes in the fluids' geochemistry. That event dramatically pushed scientists to develop new methods to monitor the seafloor venting activity. Coupling the information from geochemical investigations and data collected during the unrest of volcanic activity, we were able to (a) develop theoretical models to gain a better insight on the submarine hydrothermal system and its relationships with the local volcanic and tectonic structures and (b) to develop a preliminary submarine volcanic hazard assessment connected to the Panarea system (Aeolian Islands). In order to mitigate the potential submarine volcanic hazard, three different scenarios are described here: (1) ordinary hydrothermal venting, (2) gas burst, and (3) volcanic eruption. The experience carried out at Panarea demonstrates that the best way to face any submarine volcanic-hydrothermal hazard is to improve the collection of data in near real-time mode by multidisciplinary seafloor observatories and to combine it with periodical sampling activity.
\end{abstract}

\section{Introduction}

The seven emerged volcanoes of the Aeolian Archipelago represent the youngest volcanism that migrated southeastward from the central and southern sectors of the Tyrrhenian Sea during the Lower Pleistocene [1].

The entire volcanic arc is nowadays well known to be a multihazard prone area for which risk assessments have been constrained due to the occurrences of volcanic phenomena, seismic events, and tsunamis. According to historical catalogues [2], several strong earthquakes hit the western and central sectors of the Aeolian Archipelago (e.g., the $\mathrm{Mw}=$
6.2 in March 1786 or the recent $\mathrm{Mw}=6.1$ in April 1978) related to a NNW-SSE trending right-lateral strike-slip fault system and caused severe damages and casualties in the surrounding localities [3]. On April 20, 1988, a small landslide of approximately $200,000 \mathrm{~m}^{3}$ occurred on the external northeastern flank of the "La Fossa" crater on the island of Vulcano. The landslide fell into the sea, producing a small tsunami that was locally observed in the neighbouring harbour called Porto Levante [4].

The island of Vulcano suffered a strong explosive activity during 1888-1890 at the end of 15 years of low-energy phreatic blasts $[5,6]$. The products of that eruption (blocks 
weighing up to 5 tons) covered the area where the tourist village is located. Recently, between 1988 and the late 90s, the volcanic activity reactivated the crater fumaroles with temperatures above $700^{\circ} \mathrm{C}$; a huge amount of volcanic gases was released inside the crater. In the eastern part of the Archipelago, a variety of different eruptive periods took place at Stromboli volcano (see Francalanci et al.'s study [7] and the references therein). On December 28, 2002, a flank eruption started after almost a year of growing explosive activity from the summit craters [8]. Effusion of lava took place from several vents along the Sciara del Fuoco. Two days later, a huge flank collapse induced a $20 \mathrm{~km}^{3}$ landslide producing tsunami waves that caused damages around the island of Stromboli and other Aeolian Islands (Lipari and Vulcano) and along the Sicily and Calabria coastlines. Damages to a chemical plant and to an oil tank occurred at the industrial area in Milazzo, located 35 nautical miles away to the south of the island. Different strong paroxysms occurred at Stromboli, causing huge damages to the village of Ginostra (ca. 40 inhabitants) mainly on April 5, 2003, and March 15, 2007. The fallout of incandescent blocks with the diameters between 0.3 and $2 \mathrm{~m}$ reached ballistic distances from 400 to $1300 \mathrm{~m}$ from the craters, and some of them triggered wildfires [9]. At Stromboli (about 500 inhabitants), during the summer period, the number of residents considerably increases exceeding 5000 people [10]. The last two main eruptive crises of the Stromboli volcano of 2002-2003 and 2007 occurred in winter, which is the low-tourist season and thus did not cause any fatality. The most recent effusive eruption along the Sciara del Fuoco was in 2014; however, a permanent Strombolian explosive activity is still ongoing. The different volcanic products (blocks, ash, etc.) produce variable hazard scenarios. For instance, lava flows, pyroclastic flows, and surges are able to damage populated areas, whereas ashes emitted during intense and prolonged eruptions usually have an important effect on the air traffic. Any volcanic activity can also inject large amounts of gases and aerosols into the atmosphere during both eruptions and degassing activity, inducing a health risk for the local population. Moreover, volcanic activity can trigger secondary hazardous phenomena such as landslides and tsunamis. Different geochemical surveys carried out [11] at Vulcano island indicated that during and after periods of volcanic activity unrest, there are potential hazards deriving from endogenous gas release in the inhabited area of Vulcano Porto. The $\mathrm{CO}_{2}$ and $\mathrm{H}_{2} \mathrm{~S}$ air concentration measurements identified sites with a significant gas hazard at Levante Beach, where intense submarine degassing activity is also present. During the summer period, the number of exposed people, mainly at the Vulcano porto area, grows exponentially, often exceeding 27.000 presences, mainly composed of tourists and seasonal workers. In wintertime, the resident population is less than 800 people.

In November 3, 2002, an explosion occurred 2.5 nautical miles off Panarea island, inducing an intense and long-lasting gas eruption over a shallow depth (2 to $30 \mathrm{~m}$ deep) and $2.3 \mathrm{~km}^{2}$ wide area surrounded by the islets of Panarelli, Lisca Bianca, Bottaro, Lisca Nera, and Dattilo [12]. The "degassing crisis" lasted several months and killed all the living matter in the submarine area [13].

In contrast to the hazard assessment related to submarine volcanic activity, the volcanic-hydrothermal hazard assessments have never been estimated due to a range of reasons: (i) the submarine hydrothermal fields are mostly undiscovered, and the known ones are generally not easily accessible; (ii) the venting areas are commonly characterized by weak hydrothermal discharges which do not reflect the destructive potential of gas bursts; (iii) the hydrothermalism within the Mediterranean Sea is often associated with late volcanism keeping a steady state for the venting activity; (iv) the historical information of submarine gas burst events is significantly rarer compared to the catastrophic earthquakes and to the subaerial eruptions. All of the above-mentioned reasons led to the erroneous conclusion that the submarine hydrothermal activity is not hazardous.

The improvement of our knowledge about the submarine hydrothermal systems has to be framed in terms of life safety and environmental preservation. Hydrothermal fields in the Southern Tyrrhenian offshore are located over the seamounts [14-16] and in the coastal areas of the Aeolian Archipelago [17-21], in front of Capo Vaticano [22, 23], along the coast of Ischia island [19], in the Bay of Naples and Pozzuoli [24, 25], and off the coast of Ventotene and Zannone (Pontine Islands) [26, 27]. All the systems are characterized by $\mathrm{CO}_{2}$-rich emissions and thermal waters commonly associated to past or recent volcanic activity. Moreover, investigating the hydrothermal activity, namely, the venting activity of submarine thermal fluids, especially in steady-state volcanism, is a key tool of highlighting the behavior of residual magmatic bodies at depth and the contamination of the seawater due to natural processes (hydrothermalism) in comparison to anthropic effects. It is accepted that the seeping process is driven by active tectonic lineaments which usually control the local permeability that drives the fluids upraise and their emission rates.

The well-known and documented submarine hydrothermal manifestations located at shallow depth off Panarea island (Aeolian Islands) are located inside a large paleocaldera formed in the central part of the volcanic edifice. The main exhalative field falls within the area of the minor islets (Bottaro, Dattilo, Lisca Nera, Lisca Bianca, and Panarelli; Figure 1) about 2 miles to the east of the main island [17]. The Panarea hydrothermal field has extensively been investigated for many different reasons (e.g., in [13]): it represents an important natural laboratory in order to better understand the processes governing the thermal fluid migration from the deep reservoir to the seafloor, the impact of an active hydrothermal system on the seafloor ecology, the role of bubbling and dissolved $\mathrm{CO}_{2}$ on the living matter, and the contribution of natural gas emissions to the ocean acidifications. The geochemical features of the hot fluids provide important information on several interactions among seawater, meteoric water, magmatic gases, and hosting rocks, and they help in defining the relationship between the hot deep source and its surrounding area. 


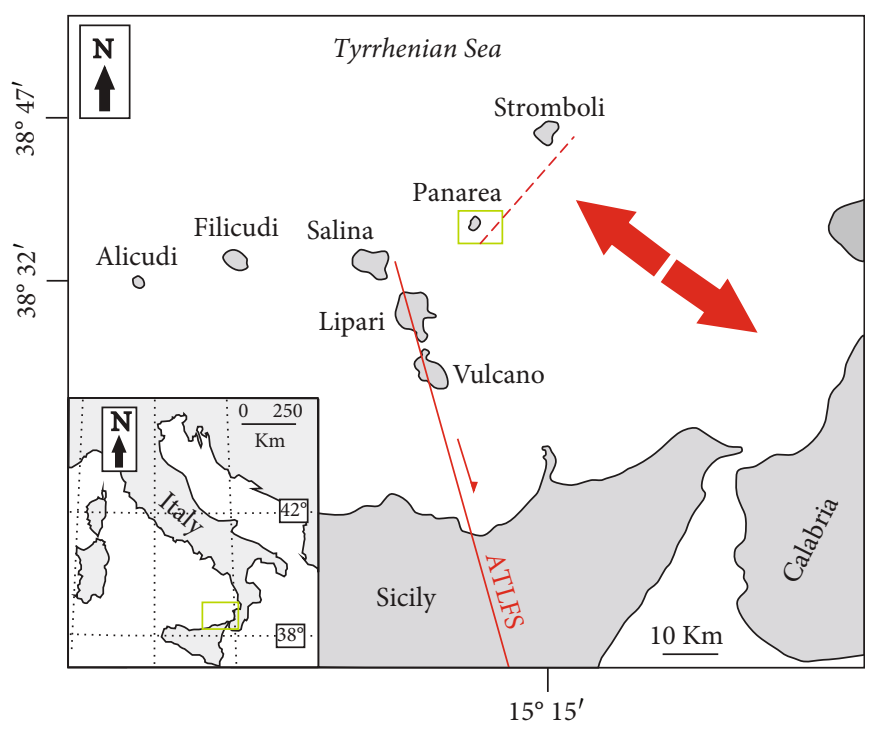

(a)

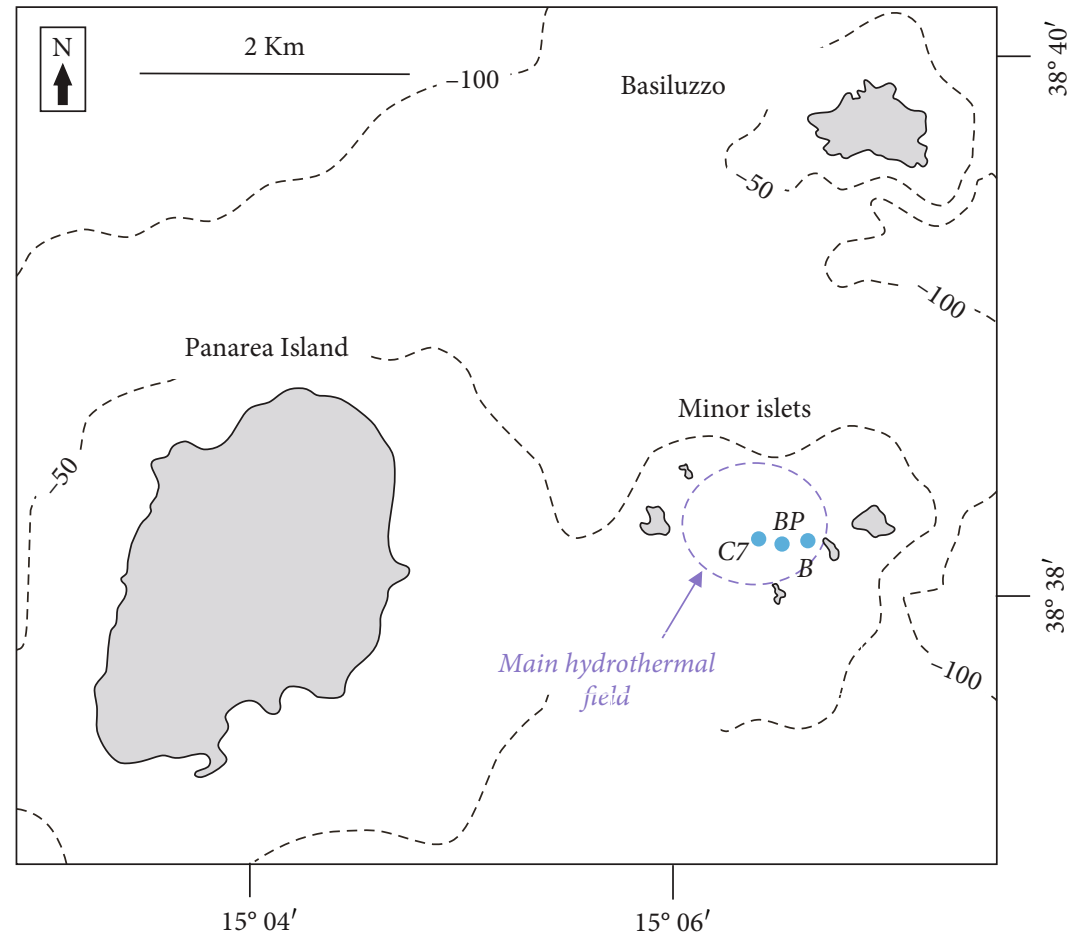

(b)

FIGURE 1: (a) Location map of the Aeolian Islands together with the main tectonic features (modified after De Astis et al. [1]). ATLFS: Aeolian-Tindari-Letojanni Fault System (Billi et al. [76]); dashed red line: N40 E fault joining Panarea and Stromboli (Heinicke et al. [43]); red arrows: late quaternary extension (Monaco and Tortorici [77]). (b) Location map of the Panarea volcanic group with the main hydrothermal field and the sampling points. C7: Campo 7 (coordinates WGS84 zone 33 N: 4276654 N-509266 E); BP: Black Point (coordinates WGS84 zone 33 N: 4276417 N-508951 E); B: Bottaro (coordinates WGS84 zone 33 N: 4276521 N-509519 E) (bathymetry after Gabbianelli et al. [34]).

The main purpose of this paper is to describe different hazard scenarios connected to the hydrothermal and volcanic activity of the Panarea volcanic island that can be of general application to correctly asses the hydrothermalismrelated hazards at least at a Mediterranean scale. Moreover, we investigate on the finest monitoring strategy to adopt in order to mitigate this kind of hazard. Considering the economic role of Panarea, one of the most important tourist destinations within the Mediterranean Sea, with an exponential increase of exposed population during the tourist season, this study could represent a useful support for the Civil Protection Authorities to perform an 


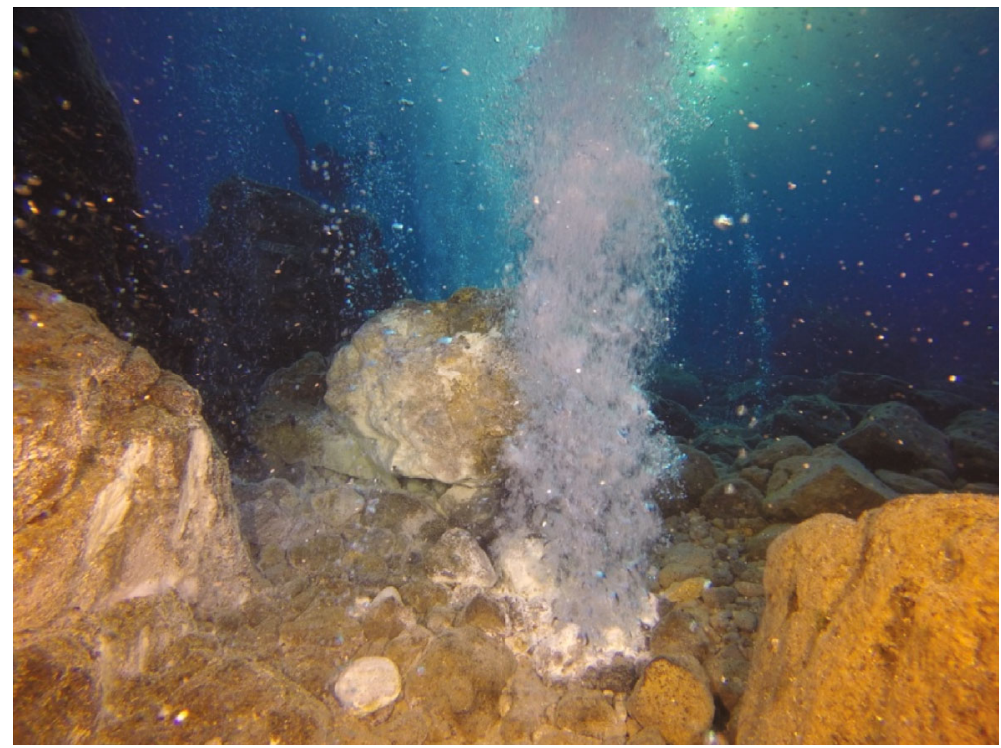

Figure 2: Hydrothermal fluids emitted from submarine vents at the main hydrothermal field (Bottaro location, 8 m.b.s.l., 2017).

appropriate emergency planning related to submarine volcanic phenomena.

\section{Geo-Volcanological Setting}

The Aeolian Archipelago is composed of seven main emerged islands (Alicudi, Filicudi, Salina, Lipari, Vulcano, Panarea, and Stromboli) (Figure 1(a)).

The Aeolian volcanism probably started during Lower Pleistocene [28], as supported by the volcanoclastic sequence interbedded within the Lower-Middle Pleistocene clays outcropping along the Tyrrhenian margin of the Peloritani Mountains [29] dated 980-589 kyr. On the contrary, the age of the oldest subaerial volcanic products has been estimated to be $260 \mathrm{kyr}$ [30-32].

Panarea is located in the eastern sector of Aeolian Islands between Stromboli and Salina volcanoes (see Figure 1(a)). The Panarea edifice rises from depths of $\sim 1700$ m.b.s.l. and consists of a truncated cone hugely modified by erosion and volcano-tectonic activities. The volcanic group is commonly defined as a dome field, and the emerged part started to assemble in $\sim 155 \mathrm{kyr}$. Around $50-60 \mathrm{kyr}$, the volcanic activity definitely shifted eastward in the minor islet area and culminated with the emplacement of the Basiluzzo dome structure. The Panarea volcanic system is formed by the main island and some minor islets (Basiluzzo, Dattilo, Panarelli, Lisca Bianca, Bottaro, and Lisca Nera) distributed over a shallow water platform (Figure 1(b)). The volcanic products drift from basaltic andesite to rhyolite compositions and show calc-alkaline and high-K calc-alkaline signatures. The main island is dissected by two tectonic systems, which have controlled the dome effusion and the feeder dyke layout. The NE-SW-oriented trend is recognized as dominant and modeled the western flank of the edifice; on the contrary, the NW-SE-oriented features are less evident and are exposed in the northern and in the southeastern portions of the island [33].

\section{Submarine Hydrothermal Activity}

The Panarea volcanic group hosts one of the most active submarine hydrothermal system of the Mediterranean Sea. The main submarine hydrothermal field is located within the area of the minor islets (Figure 1(b)) recognized as the remnants of a crater rim $[34,35]$. As reported by Italiano and Nuccio [17], several gaseous emissions spread over the sea bottom around the Panarea area up to the northeastern margin of the Basiluzzo islet, up to a depth of $400 \mathrm{~m}$ (F. Italiano, personal communication). Hydrothermal fluids come out from the main tectonic directrices crossing the Aeolian arc following NE-SW and NW-SE trending alignments $[17,36]$. Chimneys and other areas of venting fluids have recently been discovered between the island of Panarea and the islet of Basiluzzo, along a possible caldera border [13]. The tectonics drive the distribution of the hydrothermal vents, deposits, crusts, and mineralizations characterizing the whole Panarea offshore [37].

3.1. Fluid Geochemistry. The hydrothermal fluids vented at the sea bottom consist of both gases and thermal waters (see Figure 2) in which temperatures, detected at the emission points, are in the range of $40-140^{\circ} \mathrm{C}$. Table 1 summarizes the chemical and isotopic composition of the bubbling gases collected in 2015, 2016, 2017, and 2018 from three different sites located within the main geothermal field. Gases have been sampled directly from submarine vents using an inverted funnel connected to two-way glass bottles (see Italiano's study [18] for further details). The chemical composition of the bubbling gases was determined by gas chromatography (GC) using an Agilent equipped with a double TCD-FID detector and argon as the carrier gas. The gaseous samples had been admitted to the GC by a syringe, and the uncertainties are within $\pm 5 \%$. Measurements of carbon isotopic compositions $\left(\delta^{13} \mathrm{C}_{\mathrm{CO} 2}\right)$ of the vented gases were made by a Delta Plus XP IRMS equipped with a Thermo 
TABLE 1: Chemical and isotopic composition of the bubbling gases. $\mathrm{CO}_{2}, \mathrm{H}_{2} \mathrm{~S}, \mathrm{~N}_{2}$, and $\mathrm{O}_{2}$ are expressed in vol. \% and $\mathrm{H}_{2}, \mathrm{He}, \mathrm{CO}$, and $\mathrm{CH}$ in vol. ppm.

\begin{tabular}{lccccccccccccc}
\hline Sample ID & Site & Data & $\mathrm{He}$ & $\mathrm{H}_{2}$ & $\mathrm{O}_{2}$ & $\mathrm{~N}_{2}$ & $\mathrm{CO}$ & $\mathrm{CH}_{4}$ & $\mathrm{CO}_{2}$ & $\mathrm{H}_{2} \mathrm{~S}$ & $\delta^{13} \mathrm{C}_{\mathrm{CO} 2}$ & $R / R_{\mathrm{A}}$ \\
\hline 1 & Bottaro & $05 / 05 / 2015$ & 8 & 4,10 & 0,078 & 0,54 & $<1$ & 1,20 & 92,30 & 6,16 & $-2,69$ & 4,27 \\
2 & Black Point & $04 / 06 / 2015$ & 8 & 3,10 & 0,031 & 3,85 & 6 & 676 & 95,63 & 0,82 & $-2,37$ & 4,26 \\
3 & Bottaro & $05 / 06 / 2015$ & 10 & $\mathrm{bdl}$ & 0,24 & 1,06 & 11 & 22 & 95,99 & 1,31 & $-2,66$ & 4,23 \\
4 & Black Point & $02 / 09 / 2015$ & 12 & 241 & 0,077 & 0,56 & $<1$ & 895 & 97,87 & 0,52 & n.d. & 4,19 \\
5 & Bottaro & $03 / 09 / 2015$ & 8 & 4,20 & 0,0077 & 0,29 & $<1$ & $<1$ & 91,69 & 5,63 & n.d. & 4,20 \\
6 & C7 & $03 / 09 / 2015$ & 7 & 1,10 & 0,056 & 0,41 & $<1$ & 177 & 95,35 & 2,28 & n.d. & 4,24 \\
7 & Black Point & $27 / 09 / 2016$ & 11 & 211 & 0,97 & 4,51 & $<1$ & 775 & 94,19 & bdl & n.d. & 4,31 \\
8 & Bottaro & $29 / 09 / 2016$ & 8 & bdl & 0,0025 & 0,23 & 1 & 16 & 97,25 & 0,90 & n.d. & 4,31 \\
9 & Black Point & $23 / 03 / 2017$ & 11 & 5 & 0,082 & 0,55 & 13 & 769 & 98,28 & 0,65 & n.d. & 4,25 \\
10 & C7 & $08 / 05 / 2018$ & 10 & bdl & 0,067 & 0,55 & 1,10 & 186 & 96,20 & 1,60 & n.d. & 4,11 \\
11 & Bottaro & $01 / 06 / 2018$ & 9 & 5 & 0,028 & 0,34 & $<1$ & $<1$ & 91,70 & 3,83 & n.d. & 4,30 \\
\hline
\end{tabular}

bdl: below detection limits; n.d.: not detected.

TRACE GC interfaced with Thermo GC/C III. The results (expressed in $\delta^{13} \mathrm{C} \%$ ) are relative to the V-PDB (ViennaPee Dee Belemnite) standard, and the standard deviation of the ${ }^{13} \mathrm{C} /{ }^{12} \mathrm{C}$ ratio was $\pm 0.2 \%$. The $\mathrm{He}$ isotope ratio $\left({ }^{3} \mathrm{He} /{ }^{4} \mathrm{He}\right)$ was analyzed by a Helix SFT-Thermo static vacuum mass spectrometer after purification of $\mathrm{He}$ under highvacuum and cryogenic separation from Ne. Helium isotope compositions are given as $R / R_{\mathrm{A}}$, namely, ${ }^{3} \mathrm{He} /{ }^{4} \mathrm{He}$ of the sample versus the atmospheric ${ }^{3} \mathrm{He} /{ }^{4} \mathrm{He}\left(R_{\mathrm{A}}=1.386 \times 10^{-6}\right)$. Typical uncertainties are within $\pm 5 \%$.

The chemical and isotopic composition of gaseous emissions collected from 2015 to 2018 is comparable to that reported in the literature (e.g., [17]) for gases sampled during prolonged steady-state conditions. Bubbling Gases exhibit high $\mathrm{CO}_{2}$ contents ( $\sim 95-98$ vol. \%) and variable contents of $\mathrm{H}_{2} \mathrm{~S}$ (from 0 to $\sim 6.5$ vol. \%), associated to minor amounts of $\mathrm{H}_{2}, \mathrm{~N}_{2}, \mathrm{He}, \mathrm{CH}_{4}$, and $\mathrm{CO}$. The composition is strongly influenced by gas/water interaction (GWI) processes occurring at either high or low temperatures. GWI induces severe changes in the pristine geochemical features of the vented fluids due to the following: (i) steam condensation; (ii) loss of highly soluble species (i.e., $\mathrm{SO}_{2}, \mathrm{HCl}$, and $\mathrm{HF}$ ); (iii) depletion and fractionation of soluble species partially dissolved in water (i.e., $\mathrm{H}_{2} \mathrm{~S}$ and $\mathrm{CO}_{2}$ ); and (iv) enrichment in $\mathrm{He}, \mathrm{CH}_{4}$, and atmospheric components (i.e., $\mathrm{O}_{2}$ and $\mathrm{N}_{2}$ ) dissolved in seawater. The isotopic composition of carbon $\left(\delta^{13} \mathrm{C}_{\mathrm{CO} 2}\right.$ varying between $-1 \%$ and $-3 \% \mathrm{~V}-\mathrm{PDB})$ and helium $\left(R / R_{\mathrm{A}}\right.$ ranging from 4.1 to 4.4 ) clearly indicates the presence of a magmatic component in the gases [17].

The gas sample collection (2015-2018) carried out in the frame of this study is part of the periodical monitoring activity carried out by INGV over the area of Panarea.

3.2. The Submarine Panarea Crisis. The sudden unrest of submarine volcanic activity which occurred off the island of Panarea in November 2002 was interpreted as a submarine low-energy explosion that opened a "crater" of 20 by 10 meters wide and 7 meters deep [38, 39].

A huge degassing activity increased the $\mathrm{CO}_{2}$ flow rate by orders of magnitude: degassing rate estimations carried out over a $4 \mathrm{~km}^{2}$ wide hydrothermal area before the event provided an integrated flow rate in the range of $10^{7}$ litres/day of $\mathrm{CO}_{2}$, in contrast with the gas vented only by the crater, estimated to be in the order of $1-2 \times 10^{9} \mathrm{l} / \mathrm{d} \mathrm{CO}_{2}$. Due to the high solubility of $\mathrm{CO}_{2}$ in seawater, such a large amount of gas made the surrounding marine environment anoxic killing all the living matter in the area. Moreover, the injection in the atmosphere might form a cloud of about $10^{-3} \mathrm{~km}^{3}$ in the absence of wind.

According to Caliro et al. [38] and Caracausi et al. $[40,41]$, the unrest episode was caused by a sudden and short-lived input of deep magmatic fluids in the geothermal reservoir. Within a more open view, the 2002 unrest event represents the only submarine hydrothermal explosion observed in the Mediterranean Sea over modern times.

Besides the periodical sample collection (gases and hot waters for laboratory analyses), a continuous monitoring has been carried out by a seafloor observatory developed to perform near real-time data transmission [42]. Among the other sensors, the acoustic probe (hydrophone), installed for a long-term recording of the noise of the bubbling gases in a frequency range of $0.5 \mathrm{~Hz}^{-3} \mathrm{kHz}$, gave useful information for a tight tectonic link between the submarine volcanic activity of Panarea island and the crater explosions of the nearby active volcanic island of Stromboli [43].

3.3. Historical Explosive Episodes. Greek and Roman historians from the past, such as Strabo, Titus Livius, Orosius Paulus, Pliny the Elder, and Panaetius (see [44]), widely described violent exhalative events that occurred off the island of Panarea that generated heat, death of fish, and bad smells. Particularly, Strabo told about fire, flames, and ash, which appeared above the sea surface between Hiera (Vulcano island) and Euonymos (Panarea island); this event is dated $126 \mathrm{BC}$, and the geographic illustration can match the crater area location in between the minor islets in front of Panarea. Mercalli [45] reported jets of hot steam observed by Fouquè in 1865; this event was concomitant with powerful eruptions of Stromboli and Mount Etna. 


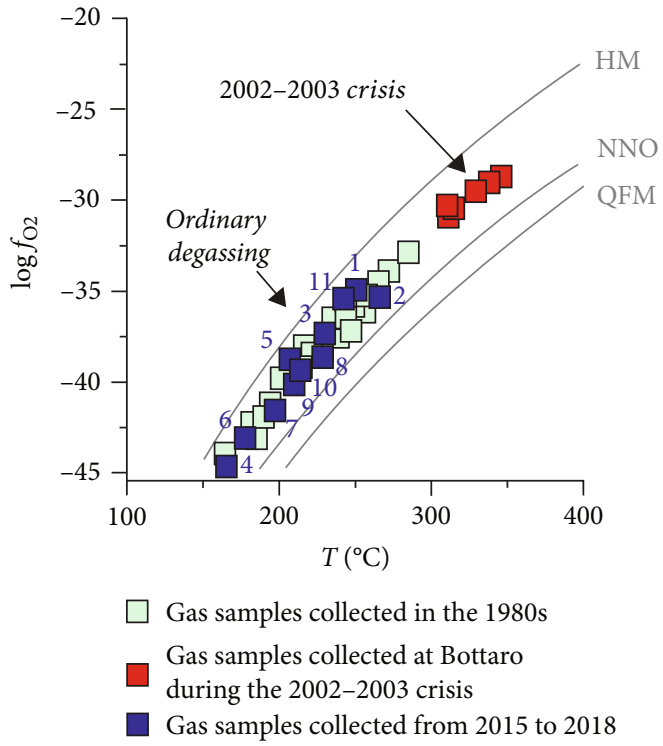

(a)

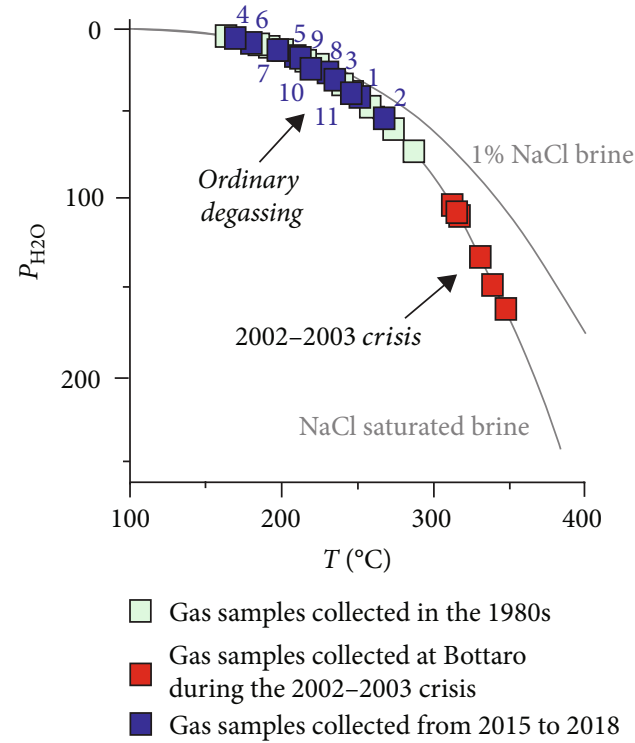

(b)

FIgURe 3: Geothermometric and geobarometric estimations (see the text for further details) of the bubbling gases collected at Panarea in the 1980s (data after [17]), during the 2002-2003 volcanic crisis (data after [40]), and from 2015 to 2018 (this paper). (a) Temperature vs. oxygen fugacity (expressed as $\log \mathrm{fO}_{2}$ ) diagram. The solid buffers quartz-fayalite-magnetite (QFM), nickel-nickel oxide (N-NO), and hematitemagnetite (HM) are plotted as reference (after Eugster and Wones [78]). (b) Estimated equilibrium pressure of the hydrothermal reservoirs. The pressure is shown on the vertical axis as $P_{\mathrm{H} 2 \mathrm{O}}$ (bars). The boiling curves for saturated $\mathrm{NaCl}$ and $1 \% \mathrm{NaCl}$ waters (brines) are shown. $P_{\mathrm{H} 2 \mathrm{O}}$ is calculated by using the estimated equilibrium temperatures.

A similar sequence can be recognized in 2002: the gas burst (November 3 ) was preceded by a sequence of tectonic events which started with $M=5.6$ earthquake $(6 / 9 / 2002$ [46]) in the Southern Tyrrhenian Sea and by the onset of the Mount Etna eruption (27/10/2002). A few weeks later $(28 / 12 / 2002)$, it was followed by the onset of an intense eruptive phase which started from the flank of Stromboli. According to Walter et al. [47], the earthquake-induced strain may have triggered fluid pressure migration within the active hydrothermal and magmatic systems, generating the Panarea gas burst and the Mount Etna and Stromboli eruptions.

Further indications about the volcanic activity related to the hydrothermal system of Panarea come from geomorphological studies carried out after the crisis (Anzidei et al. [36]; Esposito et al. [48]). The results show how the shallow water platform, located between 0 and $-30 \mathrm{~m}$ among the islets where the main Panarea hydrothermal area is located, is dotted by a large number of crater-like depressions. More than a hundred of those structures have been recorded, the biggest of them being $175 \mathrm{~m}$ wide by $5 \mathrm{~m}$ deep. It seems probable that these crater-like structures have been formed by past submarine gas explosions, quite similar to the 2002 event in terms of energy, amount of gas released, and time length; this assumption underlines the fact that this area has been very "hydrothermally" active in recent historical times.

According to Heinicke et al. [43], the seismic, volcanic, and hydrothermal activity of the Panarea volcanic group is controlled by a $\mathrm{N} 40^{\circ} \mathrm{E}$ normal fault on which Panarea and Stromboli edifices developed. In the Panarea sector, the
$\mathrm{N} 40^{\circ} \mathrm{E}$ fault and its associated fracture network symbolize the preferential way allowing the hydrothermal fluids to ascend and reach the seafloor; in this environment, a sudden increase of temperature and fluid pressure, in response to changes in the regional stress field, can generate hydrofracturing and rupture [12, 41, 48].

3.4. The Volcanic-Hydrothermal System. Fluids vented at Panarea originate from a reservoir, located at some level beneath the seafloor, kept at the boiling conditions by the thermal energy released by hot magmatic fluids [17, 40]. The results allowed Italiano and Nuccio [17] to model the hydrothermal system composed of several separated geothermal reservoirs fed by hot hydrothermal fluids with a magmatic component. The hot fluids are released by a deep geothermal reservoir $\left(T>350^{\circ} \mathrm{C}\right)$ constantly recharged by seawater and by magmatic fluids. Inside the deep geothermal reservoir, intense water-rock interactions (WRI) [17] change the original seawater composition by selective extraction of chemical elements from the hosting rocks. During the hydrothermal fluid uprising, the pressure drops inducing boiling and thus phase separation with the production of steam besides high-density liquid phases. Those fluids feed the shallower reservoirs, and the number and intensity of the interactions drive the final geochemical features of the fluids vented at the seafloor.

The chemical composition of the vented hydrothermal fluids is buffered by pressure, temperature, and redox conditions. Following the indications and constrains proposed by Italiano and Nuccio [17], we used the reactive gas 
concentrations of $\mathrm{CO}, \mathrm{CH}_{4}$, and $\mathrm{CO}_{2}$ to estimate the reservoir equilibrium temperatures. Figure 3 shows the results of the performed geothermometric and geobarometric estimations considering the analytical composition of the bubbling gases collected at the main hydrothermal vents over a 30 -year long time span including data recorded in the 1980s (after [17]), during the 2002-2003 volcanic crisis (after [40]), and from 2015 to 2018 (this work). We have to take into consideration that the temperature estimations, based on the system $\mathrm{H}_{2} \mathrm{O}, \mathrm{CO}_{2}, \mathrm{CH}_{4}$, and $\mathrm{CO}$, are reasonably valid in the range between 100 and $400^{\circ} \mathrm{C}[17,49]$. The very high $\mathrm{CO}_{2}$ solubility in seawater during GWI processes, especially in comparison to those of $\mathrm{CO}$ and $\mathrm{CH}_{4}$, provokes severe alterations of the $\mathrm{CO}_{2} / \mathrm{CO}$ and $\mathrm{CO}_{2} / \mathrm{CH}_{4}$ ratios. The slow $\mathrm{CO}$ and $\mathrm{CH}_{4}$ reaction kinetics allows them to retain their abundance ratios keeping the deep equilibrium conditions during their uprising. At the same time, due to their similar solubility coefficients, the $\mathrm{CO} / \mathrm{CH}_{4}$ ratio remains rather constant. The adopted system, however, is more sensitive to the $\mathrm{CO}$ and $\mathrm{CH}_{4}$ contents than that of $\mathrm{CO}_{2}$; thus, the extent of GWI responsible for the variations of the $\mathrm{CO}_{2}$ concentration do not influence the estimated equilibrium temperatures (see Italiano and Nuccio's study [17] and Italiano et al.'s study [50] for further details). According to Italiano and Nuccio [17], the equilibrium constants are a function of temperature and oxygen fugacity $\left(f_{\mathrm{O} 2}\right)$. The latter is buffered by the mineral assemblage (quartz, olivine, magnetite, hematite, and nickel) of the hosting rocks, whereas the temperature influences the water molecule breaking $\left(\mathrm{H}_{2} \mathrm{O}=\mathrm{H}_{2}+\left(1 / 2 \mathrm{O}_{2}\right)\right.$ ) . The results have been plotted on the already adopted temperature $\left(f_{\mathrm{O} 2}\right.$ graph) (Figure $\left.3(\mathrm{a})\right)$ showing that Panarea samples fall between two theoretical $f_{\mathrm{O} 2}$ buffers proving that an equilibrium is attained in every geothermal system. The calculated geotemperatures can also been used to constrain the depth of the geothermal reservoir (Figure 3(b)), by estimating the $P_{\mathrm{H} 2 \mathrm{O}}$ according to the $T-P_{\mathrm{H} 2 \mathrm{O}}$ relationship for $2 \mathrm{M}$ and $\mathrm{NaCl}$-saturated waters $\left(\log f_{\mathrm{H} 2 \mathrm{O}}=5.479-2047 / T\right.$; Chiodini et al. [51]). The estimations show equilibrium temperatures ranging from $150^{\circ} \mathrm{C}$ to $280^{\circ} \mathrm{C}$ with $P_{\mathrm{H} 2 \mathrm{O}}$ in the range of 5-70 bars during ordinary degassing (samples collected in the 1980s and from 2015 to 2018). Those values increased up to $350^{\circ} \mathrm{C}$ and $P_{\mathrm{H} 2 \mathrm{O}}$ ranging between 100 and 160 bars for samples collected at Bottaro during the 20022003 crisis. The higher values obtained for the samples collected during the crisis reflect the short rising time due to the high degassing rate that marked the entire crisis time. During the 2002-2003 crisis, the reactive species kept their initial concentrations that had been reached at the reservoir level, bringing the original signature up to seafloor [40].

If a steady state condition is kept at the reservoir level, no significant changes in the geochemical features of the vented hydrothermal fluids are observed with the time, with tides being the main factor acting on the fluid escape. Sudden or wide changes are clear indications that the deep magmatic feeding is not simply related to a cooling magma body, but additional processes (e.g., changes in vertical permeability due to tectonics and fluids from an active magma degassing) have occurred.

\section{Hazard Scenarios}

Concerning the last eruptive activity of the Panarea volcanic group, several doubts and uncertainties still exist. The most recent papers (e.g., Lucchi et al. [33]) indicate the Drauto pumices (Drauto Formation) as the latest products referred to the Panarea volcanism; no radiometric dating has been carried out, and the age proposed is confined between 24 and $8.7 \mathrm{kyr}$ on the basis of tephrostratigraphic relationships. The Drauto pumices are, in fact, embedded within the Upper Brown Tuffs (fallout eruption units from Vulcano island) which lie above a 27-24 kyr marker bed and below a 8.7-8.4 kyr tephra layer (both markers are external). The Drauto Formation has been interpreted as the result of moderate explosive episodes which originated from a vent situated in the area of the minor islets in light of the geochemical and mineralogical composition and the east-west decrease of thickness and grain size.

During submarine investigations, Bellia et al. [52] and Italiano and Nuccio [17] discovered basic dykes and pillow lavas near the Bottaro islet. The rocks resulted to be deeply altered by the hydrothermal activity precluding any attempt to characterize and dating those products. Their basic composition suggests a totally different age, melt evolution, and emplacement mechanism in comparison to the latest volcanic eruptions located to the East of the main island of Panarea (i.e., Basiluzzo lava dome and Drauto Formation); therefore, we could consider these dykes and pillow lavas as the result of the most recent volcanic event which occurred in this area. Further investigations found out the presence of submerged remnants of probable Roman age [52-56] close to Basiluzzo and Lisca Bianca islets, at a depth of 3-14 meters. This localized subsidence can be related to a magma chamber deflation or to the extensional neotectonic activity. Both scenarios might have been connected with volcanic eruptions.

The explosions associated with the observed craters at the main hydrothermal field have involved the sediment cover formed during the seawater rise following the Wurmian lowstand [48]; hence, they must be younger than 10.000 years at least. Considering the presence of $\sim 150$ craters within the area of the minor islets, the average probability of the occurrence of hydrothermal explosions was calculated by Monecke et al. [20] as to be one event per $\sim 65-70$ years. As a matter of fact, explosive events, such as the 2002 unrest episode, have to be considered common phenomena, and therefore, the occurrence of an explosive gas eruption cannot be ruled out.

Taking into account the above-mentioned considerations, constraints, and speculations from previous and historical works about volcanism, we hypothesize and describe three distinct hazard scenarios for the area (Table 2): (i) ordinary hydrothermal venting activity; (ii) occurrence of a gas burst; and (iii) occurrence of a volcanic eruption (Drautotype). Our scenarios are also supported by the multidisciplinary data showing the close link between hydrothermalism, volcanic, and geodynamic processes affecting the Panarea volcanic group.

4.1. Scenario 1: Ordinary Hydrothermal Venting. The potential geohazard associated to the normal discharge activity are 
TABLE 2: Hazard scenarios connected to Panarea activity.

\begin{tabular}{|c|c|c|c|}
\hline Hazard scenario & (1) Ordinary venting & (2) Gas burst & (3) Eruption (Drauto-type) \\
\hline Probability of occurrence & Permanent. & High. & Low. \\
\hline Recurrence interval & Permanent. & One event per $65 / 70$ years [20]. & Unknown. \\
\hline Hazard & Low. & High. & Very high. \\
\hline Extremely dangerous phenomena & $\begin{array}{l}\text { Constant release of } \mathrm{CO}_{2} \text { and } \\
\mathrm{H}_{2} \mathrm{~S} \text {-rich gases. }\end{array}$ & $\begin{array}{l}\text { Poisonous gas clouds (toxic clouds); } \\
\text { tsunamis. }\end{array}$ & $\begin{array}{c}\text { Intermittent eruptive columns; } \\
\text { tephra fallout; pyroclastic } \\
\text { density currents; toxic clouds; } \\
\text { tsunamis. }\end{array}$ \\
\hline Mitigation measurements & $\begin{array}{c}\text { Near real-time monitoring of } \\
\mathrm{CO}_{2} \text { and } \mathrm{H}_{2} \mathrm{~S} \text { concentrations } \\
\text { in the seawater } \\
\text { surface/atmosphere. }\end{array}$ & $\begin{array}{l}\text { Evacuation of Panarea villages } \\
\text { located downwind to the gas burst } \\
\text { area; interdiction of tourist activity } \\
\text { and marine navigation in the gas } \\
\text { burst area; near real-time } \\
\text { monitoring of the gas output and } \\
\mathrm{CO}_{2} \text { and } \mathrm{H}_{2} \mathrm{~S} \text { concentrations. }\end{array}$ & $\begin{array}{l}\text { Evacuation of the whole } \\
\text { Panarea island and the coasts } \\
\text { of the surrounding Aeolian } \\
\text { Islands; interdiction of marine } \\
\text { navigation and tourist activity. }\end{array}$ \\
\hline
\end{tabular}

mainly centered on the role of hydrothermal fluids constantly released by the submarine vents. In this situation, bubbling gases can be totally or partially dissolved in seawater during their rise through the water column as a function of their mass ratio. The possibility that deep-originated gases reach the atmosphere depends on the gas emission rate, the depth, the bubble size, the time length, and the intensity of the interactions between bubbling gases and marine waters along the seawater column. When the amount of gas vented at the seafloor increases, a larger gas fraction could reach the sea surface and interact with the lower atmosphere. This occurrence could be very hazardous to the human health, especially under certain weather conditions such as low atmospheric pressure and no wind. Those conditions may easily occur in summer during the tourist season when Panarea hosts thousands of people in land and a huge number of luxury boats in between the main island and the islets.

The bubbling gases from submarine vents are mainly composed of $\mathrm{CO}_{2}$ and $\mathrm{H}_{2} \mathrm{~S}$, and their dangerous (and sometimes lethal) effects are controlled by two factors: their concentrations and the exposure times.

Carbon dioxide $\left(\mathrm{CO}_{2}\right)$ is an odorless and colorless gas with higher density than the dry air; it is commonly defined as a "killer gas," and in the atmosphere, its content is around $400 \mathrm{ppm}$. In case of the wind absence and a continuous gas injection from the seafloor to the atmosphere, the $\mathrm{CO}_{2}$ could accumulate just over the sea surface forcing the generation of air volumes depleted in $\mathrm{O}_{2}$ and enriched in $\mathrm{CO}_{2}$. This hazardous situation could be responsible for the following: (i) asphyxia phenomena that usually appear when the $\mathrm{O}_{2}$ concentration is $<16$ vol. $\%$ and $\mathrm{O}_{2}$ concentration of $13-10$ vol. \% that could induce unconsciousness and death [57] and (ii) exposure to low-level $\mathrm{CO}_{2}$ concentration (<4 vol. \%) that could produce different short-term effects such as weakness, headache, and cough and $\mathrm{CO}_{2}$ concentration above 4 vol. \% that has been defined by Rice [58] as the IDHL (immediately dangerous to life/health) causing an immediate risk for the human health and life.

Hydrogen sulfide $\left(\mathrm{H}_{2} \mathrm{~S}\right)$ is acutely toxic and colorless, and at low concentration, it is well known for the traditional "rotten egg" smell. The $\mathrm{H}_{2} \mathrm{~S}$ may cause severe health troubles under prolonged exposures [59]. It becomes very harmful in case of long-term exposure at concentration levels of $1 \mathrm{ppm}$ : it could provoke weakness, headache, and neurological diseases. At high concentrations, in the range of 200-250 ppm, it can trigger some respiratory system diseases and death whereas at 1,000 ppm it is lethal.

4.2. Scenario 2: Gas Burst-Type Event. The results of recent geophysical investigations [48] remarked how the gas explosions are common phenomena over the submarine Panarea hydrothermal area; thus, trying to analyze the possible evolution of a gas burst event in terms of intensity, features, damages, and short-term effects has become a critical goal. According to Monecke et al. [20], the average probability of the occurrence of gas bursts is around one event per 65/70 years; this result was obtained assuming that all the $\sim 150 \mathrm{cra}-$ ters detected at the seafloor formed after the end of the glacial era, thus over the last $\sim 10 \mathrm{kyr}$. Unluckily, a valid and reliable value cannot be calculated because too many undefined factors are in play. Evaluating the onset time of crater formation is not possible; the sediment cover reworked during hydrothermal explosions represents the unique temporal marker applicable in this context. These sediments are referred to the seawater rise associated to the last lowstand, and therefore, $10 \mathrm{kyr}$ represents the oldest available time for the onset. Additionally, the fastest phase of sea level rise ended $\sim 7 \mathrm{kyr}$ [60] and we have no clear evidence that the top of the sediment cover is confined at $\sim 10 \mathrm{kyr}$. Moreover, new craters could be superimposed over the older ones, or a single crater might have been involved by more than one gas burst. For those reasons, one event per 65/70 years could be considerably underestimated. We cannot also ignore the evidence that gas burst episodes are controlled by faults (e.g., [43]), and it is extremely plausible that since $10-7 \mathrm{kyr}$ the occurrence probability has changed many times in response to changes in the tectonic activity. As a matter of fact, the current probability results to be unknown. This hypothesis is corroborated by the fact that several changes in the eruption style and in magma composition affected Stromboli during the last 15-13 ka (see Francalanci et al.'s study [7] and the references therein). These features, together with 
the multistage genesis of the Sciara del Fuoco depression, indicate that the recent volcanic evolution of Stromboli has been driven by the occurrence of tectonic pulses over the same tectonic structure in which also Panarea island developed.

We have to consider that the intensity of gas bursts can be variable and unpredictable, as testified by different shapes and extension of the craters. The released energy generally depends on the amount of the magmatic fluids injected into the geothermal reservoir at depth; for example, the energy estimate carried out for the 2002 gas burst episode was $1.3 \times 10^{8} \mathrm{~J}$ [41] and the volume of removed sediments resulted around $3 \times 10^{3} \mathrm{~m}^{3}$ [48]. The maximum potential energy that can be released as a consequence of a gas explosion caused by a 2002-like mechanism was roughly calculated by Caracausi et al. [41] in the order of $10^{9} \mathrm{~J}$.

The features expected for this scenario are the same with those observed during the burst which occurred in 2002, with changes in the geochemical composition of hydrothermal fluids, decrease of seawater $\mathrm{pH}$, total gas output enhancement along with the reworking of rocks and sediments, the death of fish, and sulfurous smell. The anomalous high gas output from seafloor (orders of magnitude higher than the ordinary degassing) drives the formation of extremely dangerous and lethal gas clouds (mostly $\mathrm{CO}_{2}$ and $\mathrm{H}_{2} \mathrm{~S}$ ) in the atmosphere just above the venting zone. Toxic clouds are the main hazardous effects correlated with this event because they can be moved by wind and reach the Panarea village, boats at the anchor, or the other islands located even several kilometers away from the venting field causing diseases or death to exposed people. A similar condition occurred during the 1650 Kolumbo submarine eruption that caused clouds of poisonous gases which reached the adjacent Santorini island $([61,62]$ and references therein). All of these aspects (i.e., $\mathrm{CO}_{2}$ and $\mathrm{H}_{2} \mathrm{~S}$ released and volume of toxic clouds and of reworked sediments) could have different impacts as a consequence of the gas burst energy.

Prevention activities in order to mitigate the potential risks of this area, mainly during summertime, consist in the evacuation of the downwind villages to the respect of the gas venting zone, with the interdiction of the entire degassing area to tourists and navigation.

An exceptionally powerful explosion could also induce submarine ruptures, collapses, and landslides with a tsunamigenic potential. According to Caracausi et al. [41], tsunamis might be triggered if the energy (and consequently the amount of volatiles involved in the gas explosion) is at least two orders of magnitude higher than that estimated for the 2002 event.

4.3. Scenario 3: Volcanic Eruption (Drauto-Type) Event. Panarea island has long been considered by local people (and scientific community as well) an extinct volcano. Italiano and Nuccio, in 1991, first proposed that the island was an active volcano based on the energy estimations related to the gas output. The most recent information and events highlight how Panarea volcanism is still active and potentially dangerous. The presence of magmatic bodies beneath the Panarea area is supported by the geochemical informa- tion coming from the bubbling gases showing $\delta^{13} \mathrm{C}_{\mathrm{CO} 2}$ values and ${ }^{3} \mathrm{He} /{ }^{4} \mathrm{He}$ ratios in the same range of those recorded at the active volcano of Stromboli. As a matter of fact, it cannot be excluded that there is a possibility that a volcanic eruption might take place in the future in agreement with Lucchi et al. [33] who pointed out that the occurrence of an explosive eruption similar to that which produced the Drauto Formation cannot be ruled out. The scientific community has interpreted the Drauto pumices as the formation which recorded the latest eruptive event(s) of Panarea; moreover, considering that no absolute evidence has been identified against it, we decided to adopt the "Drauto-type event" as the plausible scenario connected to a volcanic eruption.

The Drauto eruptions, according to Lucchi et al. [33], is composed of two distinct fallout units, probably generated from a proximal source area in the Panarea volcanic group, with a rapid east-west decrease of thickness from about $25 \mathrm{~cm}$ at Basiluzzo to $20 \mathrm{~cm}$ at Drauto, to less than $10 \mathrm{~cm}$ at Castello di Salvamento. According to Lucchi et al. [33], these fallout units were emitted from a vent located in the area of the minor islets and presently completely eroded and submerged. This provenance is supported by the high- $\mathrm{K}$ to SHO affinity (high-K andesite-dacite to latite) and the distinctive biotite-amphibole mineralogic content of the Drauto pumices, which are comparable to some volcanic products of the Lisca Bianca and Bottaro islets [63].

The Drauto-type volcanic activity can be expressed by moderate fallout eruptions from intermittent volcaniantype eruptive columns comparable to those which generated the Soldata pumices (Eruptive Epoch 2 of Panarea [33]). The volume of magma involved in a possible Drauto-type eruption could be similar to the values estimated from Drauto and Soldata pumices events $\left(1.5 \times 10^{7} \mathrm{~m}^{3}\right.$ and $2.3 \times 10^{7} \mathrm{~m}^{3}$, respectively, [33]); obviously, this assumption is purely indicative as the amount of magma emitted during volcanic eruptions depends on various aspects. This eruptive style can generate several dangerous phenomena such as toxic clouds and dilute wet-type pyroclastic density currents (PDCs); however, tephra fallout from the explosive eruptive columns is surely the most significant outcome. The fallout intensity reflects the combined effect of wind variability, column height, duration, and total erupted mass. The tephra fallout hazard assessment has recently caught the attention of some researchers [64-69], who assumed a few representative eruptive scenarios for the Phlegrean Fields and Somma-Vesuvius areas where over three million of people are perilously exposed.

The combination of different data allowed to explain the 2002 gas burst of Panarea and the following eruption at Stromboli as the result of hot fluids and magma migration through tectonic lines caused by reactivation of geodynamic structures [43]. We can infer that volcanic activity in this zone is totally controlled by the WNW-ESE extensional deformation affecting the eastern sector of the Aeolian Islands. The magmatic source sampled intermittently by the Panarea volcanism seems to be extinct, but even small movements along normal faults may cause an abrupt permeability increase which could induce hot magma rise even from zones far away from the Panarea edifice; this means 


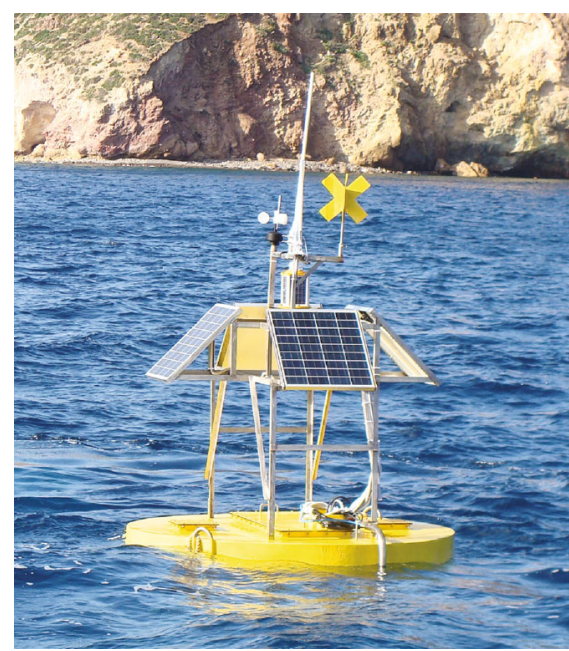

(a)

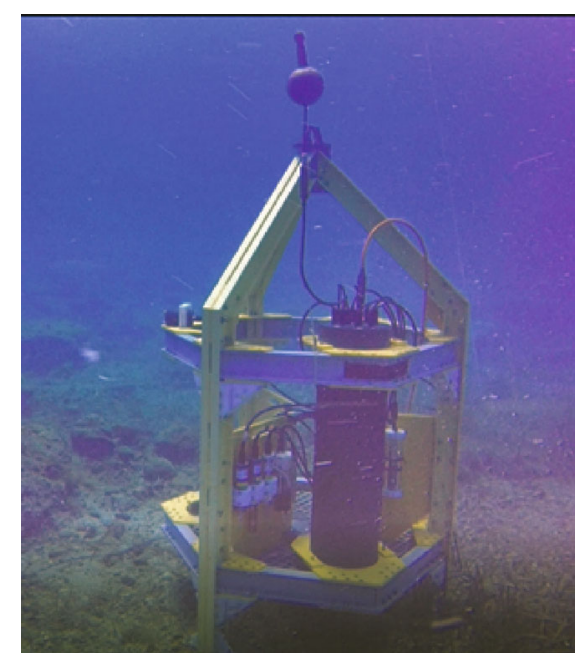

(b)

FIGURE 4: The multidisciplinary monitoring system operating within the main hydrothermal field offshore Panarea: (a) surface buoy and (b) seafloor observatory.

that the occurrence of volcanic eruptions within the Panarea area is closely addicted to the normal faulting activity. Extensional tectonics, Stromboli volcanism, and Panarea activity compose a unique geodynamic system, which can activate an enormous amount of energy; consequently, a hypothetical eruptive episode could be accompanied by tsunami waves. Among the tsunamigenic mechanisms, we can account (i) earthquakes associated to NE-SW normal faults; (ii) eruptive pulses in the minor islet area (the energy released in case of phreatomagmatic explosions can reach $10^{17}-10^{18} \mathrm{~J}[70,71]$ ); and (iii) landslides along the Stromboli cone due to earthquakes, effusive lateral eruption, and paroxysmal activity.

Regarding this scenario, it is worth noting that in view of the strong link between volcanism and tectonics, a combined approach which considers both the seafloor monitoring observatory [42] and the seismicity is largely the best way to follow in order to provide valid answers about the state and possible changes of the Panarea volcanic-hydrothermal system. In the context of managing natural hazards, prevention measurements to minimize the potential volcanic risk are the evacuation of Panarea island and the interdiction of tourist activities and marine navigation around the island and its surroundings. However, we consider the probability of occurrence of a Drauto-type eruption as extremely low.

\section{The Multidisciplinary Submarine Monitoring Activity}

A common way to minimize any natural or industrial hazard is to develop a correct monitoring activity of the main hazard factors. The monitoring activity in Panarea has been carried out following a periodical sampling of submarine vents (including bubbling gases and thermal waters) and using data from a continuous monitoring provided by an automatic system (Figure 4) made of a seafloor observatory connected by cable to a surface buoy [42]. The multidisci- plinary submarine observatory has been recently upgraded (see Italiano et al.'s study [72] and Caruso et al.'s study [73]) with the addition of a new set of sensors including a hydrophone and probes for dissolved $\mathrm{CO}_{2}, \mathrm{pH}$, and electric conductivity. Moreover, 4 temperature probes monitor the temperature at the hottest vent and in three different thermal water emissions at the seafloor around the observatory. An example of data series recorded from the seafloor observatory is reported in Figure 5.

The acoustic records are considered the proxy of the degassing activity and may provide information on sudden changes not related to natural forces: tides, waves, etc. As already observed by Heinicke et al. [43], the hydrothermal fluids vented at the hydrothermal area of Panarea have shown changes related to the volcanic activity of the nearby Stromboli island. A continuous monitoring associated to the geochemical features of the vented gases (including helium and carbon isotopic compositions) may provide important and early information on changes occurring at the submarine vents. Enhancing the surveillance system by the monitoring of $\mathrm{CO}_{2}$ and $\mathrm{H}_{2} \mathrm{~S}$ concentrations in air at the seawater interface could represent the key for success against the gas hazard related to the ordinary degassing activity, mainly at the tourist attractions in the Panarea island and its surrounding islets. Recently, many improvements have been made about the understanding of the submarine hydrothermal system of Panarea, and the near real-time monitoring of the hot fluids vented from thermal areas allows detecting variations and changes within the volcanic-hydrothermal reservoirs. Changes in $\mathrm{CO}_{2}$ concentration, increase in the temperature, and $\mathrm{pH}$ decrease of the vented fluids could represent the initial condition for an enhancement of magmatic volatiles supply. Those geochemical anomalies might be associated to the rising of deep, hot magmatic fluids, and in some cases, they could be responsible for the reactivation of the Panarea volcanic system, triggering a potential and dangerous submarine gas explosion. No evident geophysical changes preceded the 2002 submarine explosion, and GPS data demonstrated 


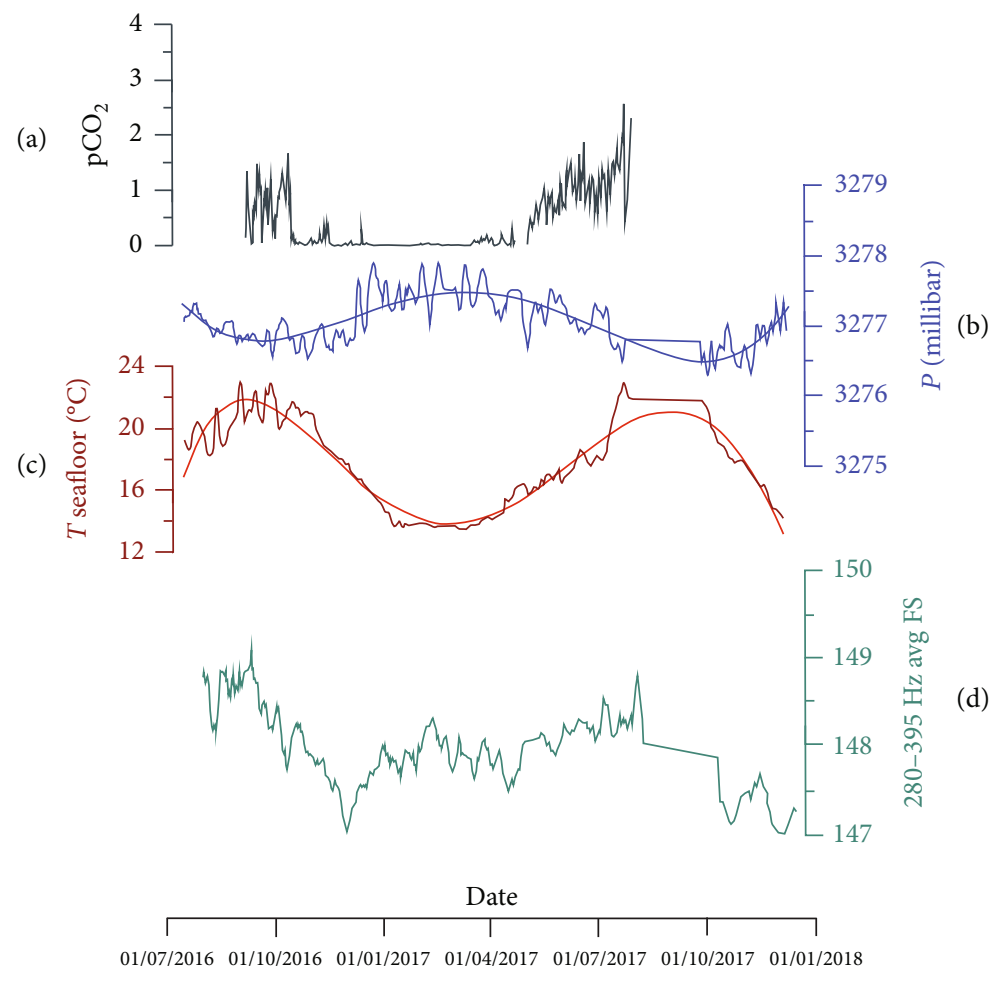

Figure 5: Example of long data series acquired by the multidisciplinary observatory: (a) percentage of dissolved $\mathrm{CO}_{2}$; (b) seafloor hydrostatic pressure together with the 3 rd order polynomial line highlighting its seasonality; (c) seafloor temperature (dark-red line) together with the 3rd order polynomial (light-red line) highlighting its seasonality; and (d) passive acoustic record RMS modulation over the range 280-395 Hz (associated to bubble stream cluster acoustic source), representing how sound pressure intensity changes over time. Acoustic series was further filtered by seasonality induced by environmental parameters.

that no significant differences in the subsidence rate had been observed before November 2002 [12]. Geochemical anomalies seem to be the most reliable resource to precociously identify changes of the Panarea volcanic system. Ordinary venting (Scenario 1) represents the permanent activity of the geothermal system of Panarea. Therefore, the values registered by the multidisciplinary observatory during the steady-state condition correspond to the threshold values to take into consideration in order to detect, and maybe anticipate, any unrest of the volcanic/hydrothermal activity as a consequence of deep inputs of thermal energy at the level of the geothermal reservoir. Taking into account the model proposed for the Panarea hydrothermal system by Italiano and Nuccio [17], the deep energy input can be transferred to shallower geothermal systems increasing their temperature and enhancing the gas output. We do not expect a gas output increase all over the submarine hydrothermal system, but only localized changes in the gas flow rates, even associated to increases of the thermal water temperature. Among the parameters automatically monitored by the seafloor observatory, the dissolved $\mathrm{CO}_{2}, \mathrm{pH}$, and acoustic data are probably the most prone to undergo severe modification during the establishment of Scenario 2 (gas burst event) as well as the temperature of the thermal waters measured at the emission point. Moreover, since the hydroacoustic noise is associated to the bubbling activity, every change of the gas flow rate (namely, change of the total gas output) is expressed by frequency shifts and increases in terms of energy (decibels) of the signal. The increase of dissolved $\mathrm{pCO}_{2}$ and the consequent drop of $\mathrm{pH}$ due to the gas flow rate enhancement can be recorded besides an increase of the magmatic component with respect to the hydrothermal one revealed by the laboratory analysis of the bubbling gases periodically taken at the seafloor. Although we might not be able to appreciate a significant increase of the outlet temperature measured by the seafloor observatory before or during a gas burst episode, the equilibrium temperatures of the fluids inside the reservoir will change a lot as it occurred during the 2002-2003 crisis when the estimated equilibrium temperatures were at least $25 \%$ higher than those calculated for the ordinary degassing (1980s and 2015-2018 data). For the above-mentioned reasons, we want to stress that the correct strategy to approach the evaluation of the hydrothermal hazard is to couple the continuous monitoring activity with periodical sampling and measurements of the vented fluids.

In the volcanic eruption case (Scenario 3), we expect severe changes in the dissolved $\mathrm{pCO}_{2}, \mathrm{pH}$, temperature, and acoustic signals due to a larger thermal energy input with respect to Scenario 2. Periodical measurements of the isotopic composition of helium in the vented fluids are very helpful to identify possible undegassed magma batches intruding underneath the deep geothermal system.

We propose that a local network of multidisciplinary seafloor monitoring observatories, as described by Italiano et al. [42], with continuous data recording and transmission, could represent the best monitoring tool in submarine volcanic 
environments, able to catch changes in the chemical and physical conditions of the hydrothermal fluids over a wide submarine area.

\section{Conclusions}

This work represents a preliminary study on the submarine volcanic-hydrothermal hazard assessment connected to the Panarea activity. Since the 2002 gas burst, this kind of hazard began to be perceived and analyzed with more care $[74,75]$, but a lot of work is still needed to be done. In this paper, three different hazard scenarios have been described with the aim of giving useful information for scientific as well as possible civil protection purposes. For the risk assessment, we have to take into account that Panarea island counts, in the winter period, less than 250 inhabitants, most of them fishermen, and no marine activities, are carried out over the area between the volcanic islands of Panarea and Stromboli. Contrastingly, during the summer season, Panarea island hosts a number of inhabitants and an order of magnitude higher than in winter, and, moreover, the area off the east coast of the island, where most of the hydrothermal vents are located, becomes a tourist attraction with hundreds of vessels per day moving over the area. In this framework, evaluating the hazard scenarios results in a key point for a correct risk assessment.

It has been observed that explosive hydrothermal episodes are driven by gas migration from deep magma source and are probably controlled by fault activity; then, we argue that geodynamic processes assume a dominant role in this area influencing the magmatic behavior of the whole eastern Aeolian sector. Changes of geochemical parameters induced by a deep gas input are crucial factors for the deep system overpressure, which could lead to the rupture and to the genesis of a potential gas explosion, favored in many cases by the extensional tectonics at a regional/local scale.

Hazard associated with submarine hydrothermalism represents a new type of challenge concerning the implementation of risk mitigation actions. Continuous monitoring of the seismic activity, gas fluxes, and geochemical parameters is the best way to deal with this significant issue in order to improve our knowledge about any submarine hydrothermal system at a global scale for which Panarea may represent a reference.

\section{Data Availability}

The data used to support the findings of this study are included within the article. In order to strenghten our assumptions, we used some geochemical data from previously reported studies which have been cited.

\section{Conflicts of Interest}

The authors declare that there are no conflicts of interest regarding the publication of this paper.

\section{Acknowledgments}

The authors wish to thank the Regional Department of Civil Protection of Sicily for the financial support. The cooperation between the Italian Civil Protection Agency, Regional Department of Civil Protection of Sicily, and National Institute of Geophysics and Volcanology has been officially determined by the Accordo Quadro DPC-INGV 2012-2021 and the DDG 30-12-2016 n.1840 agreements, respectively. The authors are also grateful to Francesco Salerno, Mariano Tantillo, Aldo Sollami, and Ygor Oliveri for their support in the laboratory work.

\section{References}

[1] G. De Astis, G. Ventura, and G. Vilardo, "Geodynamic significance of the Aeolian volcanism (Southern Tyrrhenian Sea, Italy) in light of structural, seismological and geochemical data," Tectonics, vol. 22, no. 4, article 1040, 2003.

[2] A. Rovida, M. Locati, R. Camassi, B. Lolli, and P. Gasperini, Eds., CPTI15, the 2015 version of the Parametric Catalogue of Italian Earthquakes, INGV, 2016.

[3] F. Cultrera, G. Barreca, P. Burrato et al., "Active faulting and continental slope instability in the Gulf of Patti (Tyrrhenian side of NE Sicily, Italy): a field, marine and seismological joint analysis," Natural Hazards, vol. 86, Supplement 2, pp. 253-272, 2017.

[4] S. Tinti, E. Bortolucci, and A. Armigliato, "Numerical simulation of the landslide-induced tsunami of 1988 on Vulcano Island, Italy," Bulletin of Volcanology, vol. 61, no. 1-2, pp. 121-137, 1999.

[5] G. Mercalli and O. Silvestri, "Le eruzioni dell'isola di Vulcano incominciate il 3 Agosto 1888 e terminate il 22 Marzo 1890. Relazione scientifica," Annali Ufficiali del Centenario Meteorologico e Geodinamico, vol. 10, no. 4, pp. 1-216, 1891.

[6] G. De Astis, F. Lucchi, P. Dellino et al., "Geology, volcanic history and petrology of Vulcano (central Aeolian archipelago)," in The Aeolian Islands Volcanoes, F. Lucchi, A. Peccerillo, J. Keller, C. A. Tranne, and P. L. Rossi, Eds., no. 37pp. 281349, Geological Society Memoir, 2013.

[7] L. Francalanci, F. Lucchi, J. Keller, G. De Astis, and C. A. Tranne, "Eruptive, volcano-tectonic and magmatic history of the Stromboli volcano group (north-eastern Aeolian archipelago)," in The Aeolian Islands Volcanoes, F. Lucchi, A. Peccerillo, J. Keller, C. A. Tranne, and P. L. Rossi, Eds., no. 37pp. 397-471, Geological Society Memoir, 2013.

[8] A. Bonaccorso, S. Calvari, G. Garfi, L. Lodato, and D. Patanè, "Dynamics of the December 2002 flank failure and tsunami at Stromboli volcano inferred by volcanological and geophysical observations," Geophysical Research Letters, vol. 30, no. 18, pp. 1941-1944, 2003.

[9] M. Pistolesi, D. Delle Donne, L. Pioli, M. Rosi, and M. Ripepe, "The 15 March 2007 explosive crisis at Stromboli volcano, Italy: assessing physical parameters through a multidisciplinary approach," Journal of Geophysical Research, vol. 116, no. B12, article B12206, 2011.

[10] M. Rosi, M. Pistolesi, A. Bertagnini, P. Landi, M. Pompilio, and A. Di Roberto, "Stromboli volcano, Aeolian Islands (Italy): present eruptive activity and hazards," in The Aeolian Islands Volcanoes, F. Lucchi, A. Peccerillo, J. Keller, C. A. Tranne, 
and P. L. Rossi, Eds., no. 37pp. 473-490, Geological Society Memoir, 2013.

[11] M. L. Carapezza, F. Barberi, M. Ranaldi et al., "Diffuse CO2 soil degassing and $\mathrm{CO} 2$ and $\mathrm{H} 2 \mathrm{~S}$ concentrations in air and related hazards at Vulcano Island (Aeolian arc, Italy)," Journal of Volcanology and Geothermal Research, vol. 207, no. 3-4, pp. 130-144, 2011.

[12] A. Esposito, M. Anzidei, S. Atzori, R. Devoti, G. Giordano, and G. Pietrantonio, "Modeling ground deformations of Panarea volcano hydrothermal/geothermal system (Aeolian Islands, Italy) from GPS data," Bulletin of Volcanology, vol. 72, no. 5, pp. 609-621, 2010.

[13] V. Esposito, F. Andaloro, S. Canese et al., "Exceptional discovery of a shallow-water hydrothermal site in the SW area of Basiluzzo islet (Aeolian archipelago, South Tyrrhenian Sea): An environment to preserve," PLoS ONE, vol. 13, no. 1, article e0190710, 2018.

[14] J. Lupton, C. de Ronde, M. Sprovieri et al., "Active hydrothermal discharge on the submarine Aeolian Arc," Journal of Geophysical Research, vol. 116, no. B2, article B02102, 2011.

[15] S. L. Walker, S. Carey, K. L. Bell et al., "Near-bottom water column anomalies associated with active hydrothermal venting at Aeolian arc volcanoes, Tyrrhenian Sea, Italy," in Paper presented at AGU Fall Meeting Abstracts, San Francisco, CA, USA, 2012.

[16] F. Italiano, A. de Santis, P. Favali, M. Rainone, S. Rusi, and P. Signanini, "The Marsili volcanic seamount (southern Tyrrhenian Sea): a potential offshore geothermal resource," Energies, vol. 7, no. 7, pp. 4068-4086, 2014.

[17] F. Italiano and P. M. Nuccio, "Geochemical investigations of submarine volcanic exhalations to the east of Panarea, Aeolian Islands, Italy," Journal of Volcanology and Geothermal Research, vol. 46, no. 1-2, pp. 125-141, 1991.

[18] F. Italiano, "Hydrothermal fluids vented at shallow depths at the Aeolian islands: relationships with volcanic and geothermal systems," FOG Freiberg Online Geology, vol. 22, pp. 55-60, 2009.

[19] T. L. Maugeri, G. Bianconi, F. Canganella et al., "Shallow hydrothermal vents in the southern Tyrrhenian Sea," Chemistry and Ecology, vol. 26, Supplement 1, pp. 285-298, 2010.

[20] T. Monecke, S. Petersen, M. D. Hannington et al., "Explosion craters associated with shallow submarine gas venting off Panarea island, Italy," Bulletin of Volcanology, vol. 74, no. 9, pp. 1937-1944, 2012.

[21] S. Graziani, S. E. Beaubien, S. Bigi, and S. Lombardi, "Spatial and temporal $\mathrm{pCO}_{2}$ marine monitoring near Panarea Island (Italy) using multiple low-cost GasPro sensors," Environmental Science and Technology, vol. 48, no. 20, pp. 12126-12133, 2014.

[22] M. F. Loreto, F. Pepe, R. De Ritis et al., "On the relationships between tectonics and volcanism in the offshore capo Vaticano, SE Tyrrhenian Sea, during the Plio-Pleistocene," Rendiconti Online Società Geologica Italiana, vol. 31, no. 1, pp. 85-98, 2014.

[23] M. F. Loreto, F. Italiano, D. Deponte, L. Facchin, and F. Zgur, "Mantle degassing on a near shore volcano, SE Tyrrhenian Sea," Terra Nova, vol. 27, no. 3, pp. 195-205, 2015.

[24] S. Passaro, S. Genovese, M. Sacchi et al., "First hydroacoustic evidence of marine, active fluid vents in the Naples Bay continental shelf (Southern Italy)," Journal of Volcanology and Geothermal Research, vol. 285, pp. 29-35, 2014.
[25] S. Passaro, S. Tamburrino, M. Vallefuoco et al., "Seafloor doming driven by degassing processes unveils sprouting volcanism in coastal areas," Scientific Reports, vol. 6, no. 1, article 22448, 2016.

[26] M. Ingrassia, E. Martorelli, A. Bosman, L. Macelloni, A. Sposato, and F. L. Chiocci, "The Zannone Giant Pockmark: first evidence of a giant complex seeping structure in shallowwater, central Mediterranean Sea, Italy," Marine Geology, vol. 363, pp. 38-51, 2015.

[27] F. Italiano, D. Romano, C. Caruso, M. Longo, A. Corbo, and G. Lazzaro, "Magmatic signature in submarine hydrothermal fluids vented offshore Ventotene and Zannone Islands (Pontine Archipelago, Central Italy)," Geofluids, vol. 2019, Article ID 8759609, 15 pages, 2019.

[28] L. Beccaluva, G. Gabbianelli, F. Lucchini, P. L. Rossi, and C. Savelli, "Petrology and K/Ar ages of volcanics dredged from the Eolian seamounts: implications for geodynamic evolution of the southern Tyrrhenian basin," Earth and Planetary Science Letters, vol. 74, no. 2-3, pp. 187-208, 1985.

[29] M. Di Bella, F. Italiano, G. Sabatino et al., "Pleistocene volcaniclastic units from North-Eastern Sicily (Italy): new evidence for calc-alkaline explosive volcanism in the Southern Tyrrhenian Sea," Geologica Carpathica, vol. 67, no. 4, pp. 371-389, 2016.

[30] E. Leocat, Histoire eruptive des volcans du secteur occidental des Iles Eoliennes (Sud de la Mer Tyrrhenienne, Italie) et evolution temporelle du magmatisme, Unpublished $\mathrm{PhD}$ thesis, University of Paris 11 Orsay, France, 2011.

[31] E. Leocat, P. Y. Gillot, and A. Peccerillo, “Temporal evolution of the western and central volcanism of the Aeolian Island Arc (Italy, southern Tyrrhenian Sea)," in Paper presented at EGU General Assembly, Geophysical Research Abstracts, vol. 11, Vienna, Austria, 2009.

[32] E. Leocat, P. Y. Gillot, and A. Peccerillo, "Eruptive history of western and central Aeolian volcanoes (South Tyrrhenian Sea): insights from K/Ar dating," in 44th Annual conference of the Volcanic and Magmatic Studies Group (VMSG), Geological Society of London and Mineralogical Society, Abstract Volume, 2010.

[33] F. Lucchi, C. A. Tranne, A. Peccerillo, J. Keller, and P. L. Rossi, "Geological history of the Panarea volcanic group (eastern Aeolian archipelago)," in The Aeolian Islands Volcanoes, F. Lucchi, A. Peccerillo, J. Keller, C. A. Tranne, and P. L. Rossi, Eds., no. 37pp. 3-11, Geological Society Memoir, 2013.

[34] G. Gabbianelli, C. Romagnoli, P. L. Rossi, and N. Calanchi, "Marine geology of the Panarea-Stromboli area (Aeolian Archipelago, Southeastern Tyrrhenian Sea)," Acta Vulcanologica, vol. 3, pp. 11-20, 1993.

[35] P. L. Rossi, G. Bocchi, N. Calanchi, G. Lanzafame, F. Lucchini, and R. Romano, "Evoluzione vulcano-tettonica e geochimica dell'apparato di Panarea (Isole Eolie)," Rendiconti Società Italiana di Mineralogia e Petrografia, vol. 41, no. 1, pp. 144-145, 1986.

[36] M. Anzidei, A. Esposito, G. Bortoluzzi, and F. De Giosa, "The high resolution bathymetric map of the exhalative area of Panarea Aeolian islands, Italy," Annals of Geophysics, vol. 48, no. 6, pp. 899-921, 2005.

[37] F. Gamberi, M. Marani, and C. Savelli, "Tectonic, volcanic and hydrothermal features of a submarine portion of the Aeolian arc (Tyrrhenian Sea)," Marine Geology, vol. 140, no. 1-2, pp. $167-181,1997$. 
[38] S. Caliro, A. Caracausi, G. Chiodini et al., "Evidence of a recent input of magmatic gases into the quiescent volcanic edifice of Panarea, Aeolian Islands, Italy," Geophysical Research Letters, vol. 31, no. 7, article L07619, 2004.

[39] B. Capaccioni, F. Tassi, O. Vaselli, D. Tedesco, and R. Poreda, "Submarine gas burst at Panarea Island (southern Italy) on 3 November 2002: A magmatic versus hydrothermal episode," Journal of Geophysical Research, vol. 112, no. B5, article B05201, 2007.

[40] A. Caracausi, M. Ditta, F. Italiano et al., "Changes in fluid geochemistry and physico-chemical conditions of geothermal systems caused by magmatic input: The recent abrupt outgassing off the island of Panarea (Aeolian Islands, Italy)," Geochimica et Cosmochimica Acta, vol. 69, no. 12, pp. 3045-3059, 2005.

[41] A. Caracausi, M. Ditta, F. Italiano, M. Longo, P. M. Nuccio, and A. Paonita, "Massive submarine gas output during the volcanic unrest off Panarea Island (Aeolian arc, Italy): inferences for explosive conditions," Geochemical Journal, vol. 39, no. 5, pp. 459-467, 2005.

[42] F. Italiano, R. Maugeri, A. Mastrolia, and J. Heinicke, "SMM, a new seafloor monitoring module for real-time data transmission: an application to shallow hydrothermal vents," Procedia Earth and Planetary Science, vol. 4, pp. 93-98, 2011.

[43] J. Heinicke, F. Italiano, R. Maugeri et al., "Evidence of tectonic control on active arc volcanism: the Panarea-Stromboli tectonic link inferred by submarine hydrothermal vents monitoring (Aeolian arc, Italy)," Geophysical Research Letters, vol. 36, no. 4, article L04301, 2009.

[44] Storia Geofisica Ambientale, Fenomeni vulcanici nell'arcipelago delle Eolie dall'antichita 'al XX secolo, vol. 156, Studio di fattibilita' RPT, Bologna, Italy, 1996.

[45] G. Mercalli, "Vulcani e fenomeni Vulcanici," in Geologia d'Italia, G. Negri, A. Stoppani, and G. Mercalli (Milano), Eds., p. 374, F. Vallardi, Milan, Italy, 1883.

[46] R. Azzaro, M. S. Barbano, R. Camassi et al., "The earthquake of 6 September 2002 and the seismic history of Palermo (northern Sicily, Italy): implications for the seismic hazard assessment of the city," Journal of Seismology, vol. 8, no. 4, pp. 525-543, 2004.

[47] T. R. Walter, R. Wang, V. Acocella, M. Neri, H. Grosser, and J. Zschau, "Simultaneous magma and gas eruptions at three volcanoes in southern Italy: an earthquake trigger?," Geology, vol. 37, no. 3, pp. 251-254, 2009.

[48] A. Esposito, G. Giordano, and M. Anzidei, "The 2002-2003 submarine gas eruption at Panarea volcano Aeolian Islands, Italy: volcanology of the seafloor and implications for the hazard scenario," Marine Geology, vol. 227, no. 1-2, pp. 119-134, 2006.

[49] W. F. Giggenbach, "Redox processes governing the chemistry of fumarolic gas discharges from White Island, New Zealand," Applied Geochemistry, vol. 2, no. 2, pp. 143-161, 1987.

[50] F. Italiano, A. Sasmaz, G. Yuce, and O. O. Okan, "Thermal fluids along the East Anatolian Fault Zone (EAFZ): geochemical features and relationships with the tectonic setting," Chemical Geology, vol. 339, pp. 103-114, 2013.

[51] G. Chiodini, L. Marini, and M. Russo, "Geochemical evidence for the existence of high-temperature hydrothermal brines at Vesuvio volcano, Italy," Geochimica et Cosmochimica Acta, vol. 65, no. 13, pp. 2129-2147, 2001.

[52] S. Bellia, F. Italiano, and P. M. Nuccio, Le strutture sommerse ad Est di Panarea (Isole Eolie): definizione di una loro natura antropica sulla base di studi mineralogici, petrografici e geochimici, no. 3, 1987Rapp. int. IGF- CNR, 1987.

[53] M. Anzidei, A. Esposito, and A. Benini, "Using Roman age submerged structures as levelling benchmarks: Interactions between recent sea level variations and crustal deformations," in Paper presented at EGS Meeting, European Geophysical Society, 2002.

[54] M. Anzidei, A. Esposito, and A. Benini, "Evidence of active subsidence at Basiluzzo island (Aeolian islands, southern Italy) inferred from a Roman age wharf," Quaternary International, vol. 332, pp. 143-150, 2014.

[55] A. Tallarico, M. Dragoni, M. Anzidei, and A. Esposito, "Modeling long-term ground deformation due to the cooling of a magma chamber: Case of Basiluzzo island, Aeolian Islands, Italy," Journal of Geophysical Research, vol. 108, no. B12, article 2568, 2003.

[56] F. Lucchi, C. A. Tranne, N. Calanchi, and P. L. Rossi, "Late Quaternary deformation history of the volcanic edifice of Panarea, Aeolian Arc, Italy," Bulletin of Volcanology, vol. 69, no. 3, pp. 239-257, 2007.

[57] S. A. Rice, "Health effects of acute and prolonged $\mathrm{CO}_{2}$ exposure in normal and sensitive populations," in Proceedings Second Annual Conference on Carbon Sequestration, Alexandria, VA, USA, 2003.

[58] S. A. Rice, "Human health risk assessment of $\mathrm{CO}_{2}$ : survivors of acute high-level exposure and populations sensitive to prolonged low level exposure," in Paper presented at 3rd Annual conference on carbon sequestration, Alexandria, VA, USA, 2004.

[59] M. Durand and J. G. Wilson, "Spatial analysis of respiratory disease on an urbanized geothermal field," Environmental Research, vol. 101, no. 2, pp. 238-245, 2006.

[60] K. Lambeck, F. Antonioli, M. Anzidei et al., "Sea level change along the Italian coast during the Holocene and projections for the future," Quaternary International, vol. 232, no. 1-2, pp. 250-257, 2011.

[61] P. Nomikou, S. Carey, D. Papanikolaou et al., "Submarine volcanoes of the Kolumbo volcanic zone NE of Santorini Caldera, Greece," Global and Planetary Change, vol. 90-91, pp. 135151, 2012.

[62] P. Nomikou, S. Carey, K. L. C. Bell et al., “Tsunami hazard risk of a future volcanic eruption of Kolumbo submarine volcano, NE of Santorini caldera, Greece," Natural Hazards, vol. 72, no. 3, pp. 1375-1390, 2014.

[63] N. Calanchi, A. Peccerillo, C. A. Tranne et al., "Petrology and geochemistry of volcanic rocks from the island of Panarea: implications for mantle evolution beneath the Aeolian island arc (southern Tyrrhenian sea)," Journal of Volcanology and Geothermal Research, vol. 115, no. 3-4, pp. 367-395, 2002.

[64] R. Cioni, A. Longo, G. Macedonio et al., “Assessing pyroclastic fall hazard through field data and numerical simulations: example from Vesuvius," Journal of Geophysical Research, vol. 108, no. B2, article 2063, 2003.

[65] R. Cioni, A. Bertagnini, R. Santacroce, and D. Andronico, "Explosive activity and eruption scenarios at SommaVesuvius (Italy): towards a new classification scheme," Journal of Volcanology and Geothermal Research, vol. 178, no. 3, pp. 331-346, 2008.

[66] G. Macedonio, A. Costa, and A. Folch, "Ash fallout scenarios at Vesuvius: numerical simulations and implications for hazard assessment," Journal of Volcanology and Geothermal Research, vol. 178, no. 3, pp. 366-377, 2008. 
[67] A. Costa, F. Dell'Erba, M. A. di Vito et al., “Tephra fallout hazard assessment at the Campi Flegrei caldera (Italy)," Bulletin of Volcanology, vol. 71, no. 3, pp. 259-273, 2009.

[68] J. Selva, A. Costa, W. Marzocchi, and L. Sandri, "BET_VH: exploring the influence of natural uncertainties on long-term hazard from tephra fallout at Campi Flegrei (Italy)," Bulletin of Volcanology, vol. 72, no. 6, pp. 717-733, 2010.

[69] L. Sandri, A. Costa, J. Selva et al., "Beyond eruptive scenarios: assessing tephra fallout hazard from Neapolitan volcanoes," Scientific reports, vol. 6, no. 1, article 24271, 2016.

[70] G. S. Gorshkov, "Gigantic eruption of the volcano Bezymianny," Bulletin Volcanologique, vol. 20, no. 1, pp. 77-109, 1959.

[71] K. Nakamura, "Energy dissipated with volcanic activities. Classification and evolution," Bulletin of the Volcanological Society of Japan, vol. 10, pp. 81-90, 1965.

[72] F. Italiano, C. Caruso, A. Corbo, G. Lazzaro, and P. Favali, "Hydrothermal fluids vented at shallow depths at the Aeolian Islands (Italy): geochemical features and automatic monitoring systems," in Abstracts of 13th International Conference on Gas Geochemistry, Chinese Academy of Sciences, Guangzhou Institute of Geochemistry, Chengdu, China, 2015.

[73] C. Caruso, G. Lazzaro, M. Longo, D. Romano, S. Scirè Scappuzzo, and F. Italiano, "New insights into submarine hydrothermal system phenomena revealed by acoustic monitoring technologies," in Abstract of 3rd Italian marine geologist Conference, The marine geology in Italy, Società Geologica Italiana, Rome, Italy, 2019.

[74] G. Chiodini, S. Caliro, G. Caramanna et al., "Geochemistry of the submarine gaseous emissions of Panarea (Aeolian Islands, Southern Italy): magmatic vs. hydrothermal origin and implications for volcanic surveillance," Pure and Applied Geophysics, vol. 163, no. 4, pp. 759-780, 2006.

[75] F. Tassi, B. Capaccioni, G. Caramanna et al., "Low-pH waters discharging from submarine vents at Panarea Island (Aeolian Islands, southern Italy) after the 2002 gas blast: origin of hydrothermal fluids and implications for volcanic surveillance," Applied Geochemistry, vol. 24, no. 2, pp. 246-254, 2009.

[76] A. Billi, G. Barberi, C. Faccenna, G. Neri, F. Pepe, and A. Sulli, "Tectonics and seismicity of the Tindari Fault System, southern Italy: crustal deformations at the transition between ongoing contractional and extensional domains located above the edge of a subducting slab," Tectonics, vol. 25, no. 2, article 2006, 2006.

[77] C. Monaco and L. Tortorici, "Active faulting in the Calabrian arc and eastern Sicily," Journal of Geodynamics, vol. 29, no. 3-5, pp. 407-424, 2000.

[78] H. P. Eugster and D. R. Wones, "Stability relations of the ferruginous biotite, annite," Journal of Petrology, vol. 3, no. 1, pp. 82-125, 1962. 

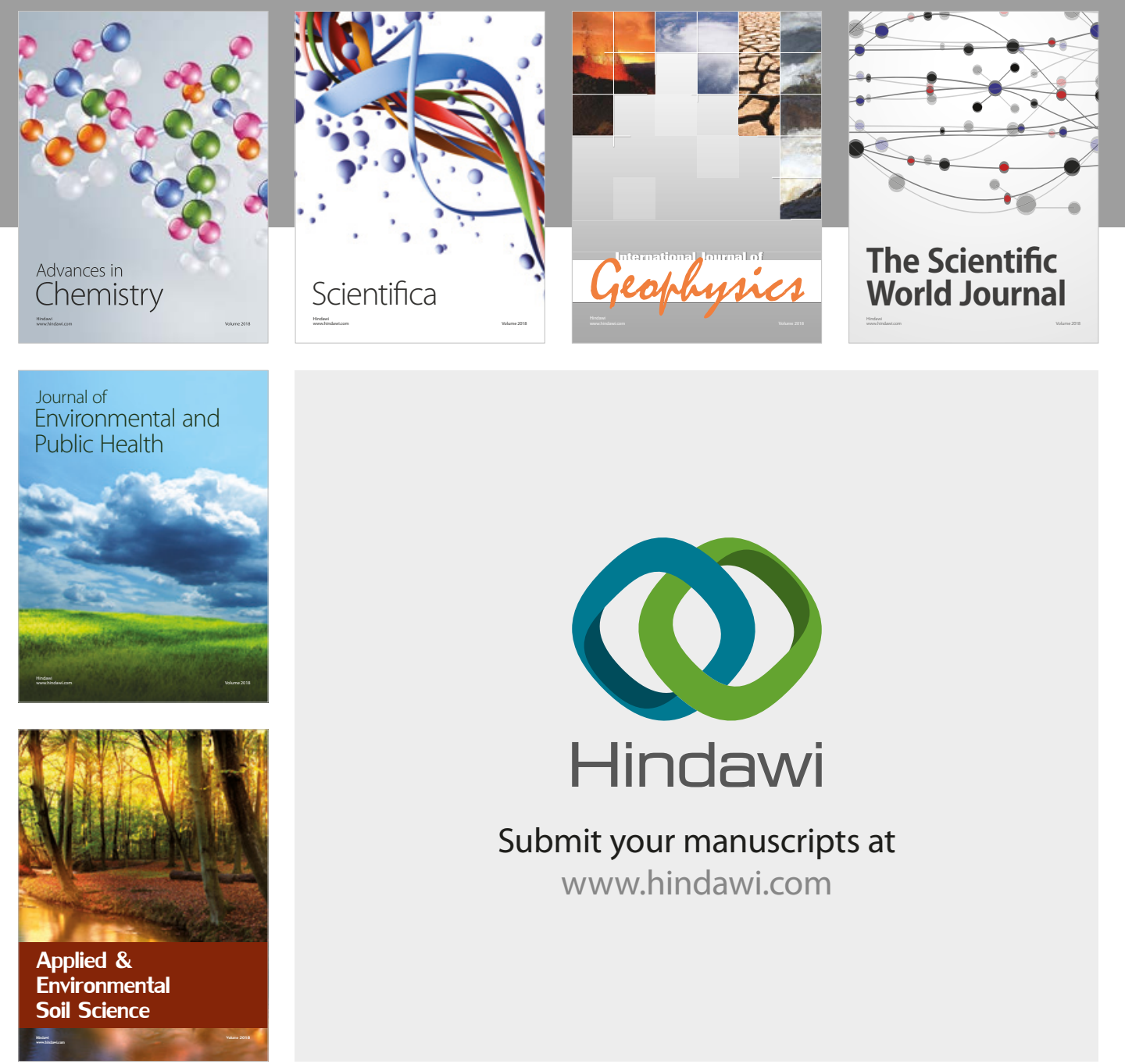

The Scientific

\section{World Journal}
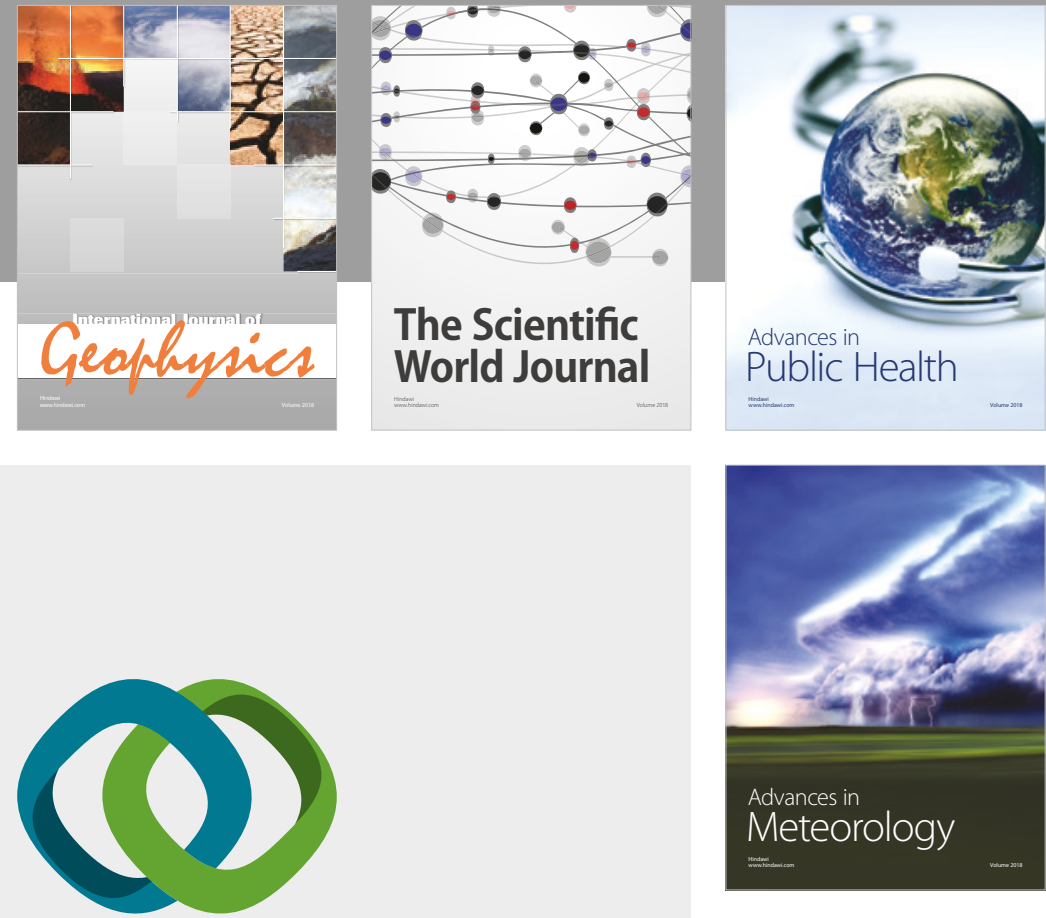

Advan

Public Health

\section{Hindawi}

Submit your manuscripts at

www.hindawi.com
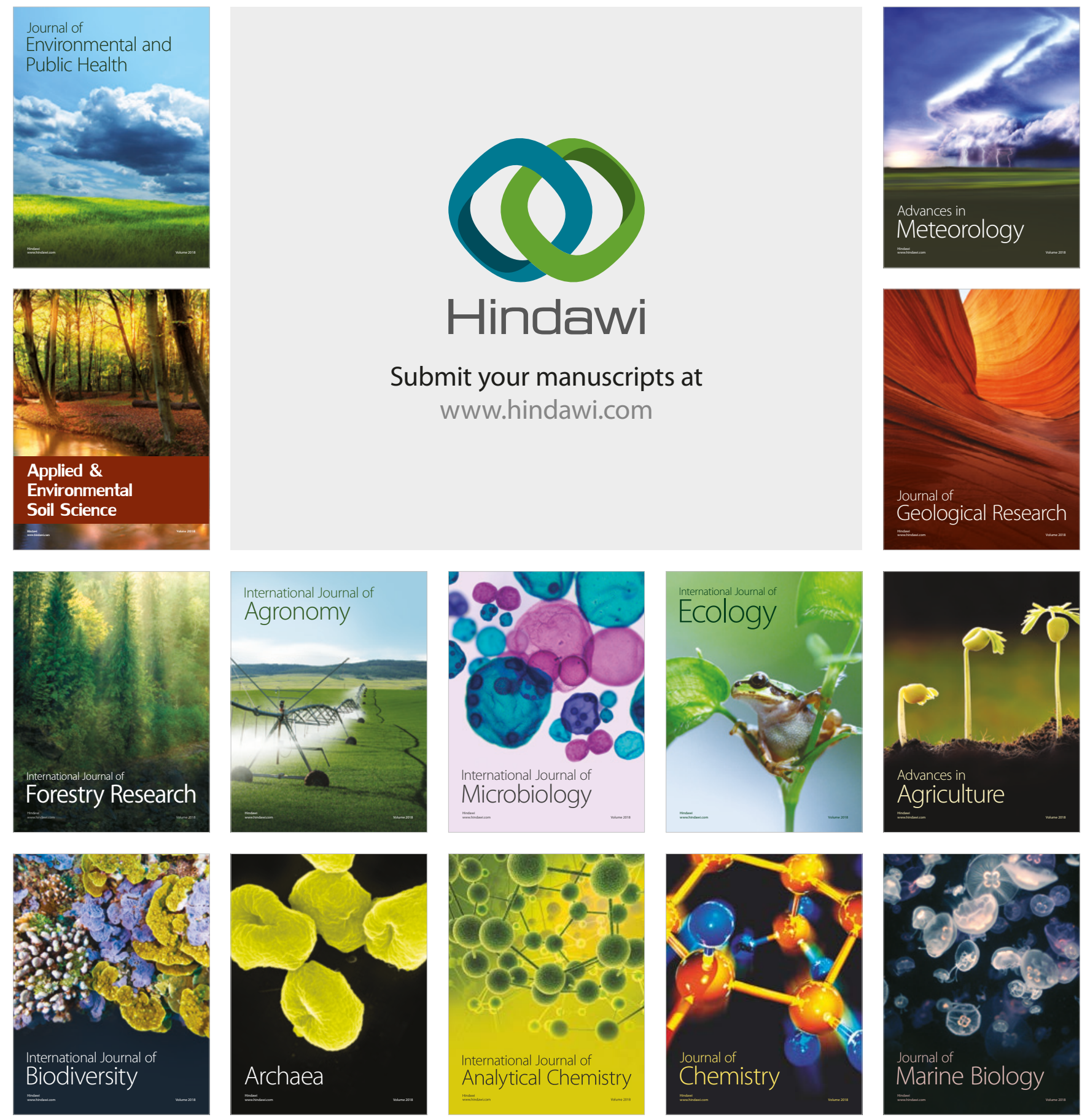